\title{
Recent legal responses to child marriage in Southern Africa: The case of Zimbabwe, South Africa and Malawi
}

\author{
Lea Mwambene* \\ Associate Professor of Law, University of the Western Cape, South Africa
}

\begin{abstract}
Summary
Child marriage occurs when one of the parties is below the age of 18 years. In Zimbabwe, South Africa and Malawi research has shown that most child marriages are linked to harmful practices that are embedded in culture. Law reform to end child marriage, therefore, is a difficult task since it presents a potential conflict between children's rights and cultural rights. This article critically examines how these selected countries seek to address the conflict between cultural practices that lead to child marriage and the protection of children's rights. It also highlights conceptual as well as practical difficulties that law reformers face in regulating cultural practices, and the gaps in the reforms that need to be addressed.
\end{abstract}

Key words: child marriage; cultural practices; law reforms; Southern Africa

LLB (Hons) (Malawi) LLM LLD (Western Cape); Imwambene@uwc.ac.za. This work is based on the research supported in part by the National Research Foundation of South Africa (NRF), Unique Grant 99216, the Law Faculty Research Funds, and the Private Law Department Funds of the University of the Western Cape. Any opinion, finding and conclusions or recommendations expressed in this material is that of the author and the NRF does not accept any liability in this regard. Special thanks go to Prof Bernard Martin, University of the Western Cape, for his generous financial support that made it possible to present this paper at the Association of American Law School Annual Meeting held in San Diego, California, 4 January 2018. 


\section{Introduction}

The global campaign, led by the consortium Girls Not Brides ${ }^{1}$ and the African Union Campaign to End Child Marriage, ${ }^{2}$ has put child marriage ${ }^{3}$ in Africa in the spotlight. ${ }^{4}$ Girls Not Brides estimates that '15 of the 20 countries with the highest rates of child marriages in the world come from Africa'.5 In sub-Saharan Africa it is estimated that 39 per cent of girls are married before their 18th birthday; while 13 per

1 Girls Not Brides: The Global Partnership to End Child Marriage (Girls Not Brides) is a global partnership of more than 800 civil society organisations. It is committed to ending child marriages and enabling girls to fulfil their potential. It was introduced in September 2011 by a group of independent global leaders working together for peace and human rights. Girls Not Brides became an independent charity in 2013, www.sharednation.org/collections/shared-nation-fall-2017/ products/girls-not-brides (accessed 8 December 2017).

2 The African Union Campaign to End Child Marriage was launched in 2014 at the AU headquarters in Addis Ababa, Ethiopia, and adopted at the African Union Summit in June 2015 (see http://pages.au.int/sites/default/files/AU\%Common \%20Position\%20on\%20Ending\%20Child\%20Marriage_English_0.pdf (accessed 6 December 2017). The Campaign is organised in partnership with the United Nations International Children's Fund (UNICEF) and United Nations Fund for Population Activities (UNIFPA). It brings together a wide range of partners including the Ford Foundation; the United Nations Economic Commission for Africa (UNECA); Save the Children; Plan International; Africa Child Policy Forum (ACPF); and the UK Department for International Development (DFID). The aim of the Campaign is to promote, protect and advocate the rights of women and girls in Africa. It is complemented by country launches in several countries where child marriage is common, as well as by the adoption of the African Union Common Position on Ending Child Marriage. Human Rights Watch Ending Child Marriage in Africa observed that in September 2015, leaders from Africa joined other governments from around the world in adopting the United Nations Sustainable Development Goals (SDGs) including a target to end child marriage in the next 15 years; https://www.hrw.org/news/2015/12/09/ending-child-marriage-africa (accessed 11 December 2017).

3 According to Plan 18+ Programme on Ending Child Marriage in Southern Africa: Policy Brief: Ending Child Marriage in Zimbabwe: Gaps and Opportunities in Legal and Regulatory Frameworks, child marriage is any marriage where at least one of the parties is under 18 years of age. See also para 19 of the Joint General Recommendation/General Comment 31 of the Committee on the Elimination of Discrimination against Women (CEDAW) and 18 of the Committee on the Rights of the Child on Harmful Practices, CEDAW/C/GC/31/CRC/C/GC/18, in which it was considered that child marriage is a form of forced marriage given that one or both parties have not expressed their full, free and informed consent.

4 All African countries are faced with the challenge of child marriage, whether with a high prevalence such as Niger at $75 \%$ or a low prevalence such as South Africa at $6 \%$. See also observations made by J Sloth-Nielsen 'Child marriage in Zimbabwe: The Constitutional Court rules no' in B Atkin (ed) International survey of family law (2016) 537 at 538.

5 Worldwide, it is estimated that every year 15 million girls are married before the age of 18 years, www.sharednation.org/collections/shared-nation-fall-2017/ products/girls-not-brides (accessed 8 December 2017). According to a 2015 UNICEF report, 'The State of the World's Children 2015: Reimagine the future', between 2005 and 201320 countries with the highest rates of child marriage before age 18 include Niger (76\%); Chad and Central African Republic (68\%); Bangladesh (65\%); Mali (55\%); Burkina Faso and South Sudan (52\%); Malawi (50\%); Mozambique (48\%); India (47\%); Lesotho (45\%); Sierra Leone (44\%); Zambia (42\%); Dominican Republic (41\%); Nepal (41\%); Ethiopia and Eritrea 
cent are married by their 15 th birthday. ${ }^{6}$ Child brides are most likely to be found in rural areas, among the poorest and most illiterate segments of the population. ${ }^{7}$ Among other factors, child marriage in Africa has been linked to harmful practices (to be discussed later) that are embedded in culture. ${ }^{8}$ This is compounded by the fact that in many African communities drifting from tradition could mean exclusion from the community. ${ }^{9}$ Law reform to end child marriage, therefore, is a difficult task since it presents a potential conflict between children's rights and cultural rights. According to the United Nations Children's Fund (UNICEF), 'the fastest progress in reducing child marriage in Africa has been in the northern region, with Southern Africa lagging behind' ${ }^{10}$ Yet, all Southern African countries are state parties to the major international and regional instruments

(41\%); and Uganda and Cuba (40\%). See also World Vision 'Ten worst places for child marriages' http://www.worldvision.org/newsstoriesvideos/ten-worst-placeschild-marriage (accessed 2 December 2017).

6 UNICEF 'The state of the world's children 2015: Reimagine the future', data.unicef.org/wp_content/upload/2015/12/

sowc_2015_Summary_and_Tables_210.pdf (accessed 8 December 2017).

7 UNICEF https://data.unicef.org/wp-content/uploads/2015/11/UNICEF-Child-Marri age-Brochure-High-Single_246.pdf (accessed 11 December 2017). It is also common in countries where literacy levels are low.

8 It is widely observed that some cultures put pressure on parents to marry off their daughters in an effort to prevent them from becoming sexually active before marriage; http://www.icrw.org/child-marriage-facts-and-figures (accessed 8 December 2017). See also observations by L Mwambene \& H Kruuse 'The thin edge of the wedge: Ukuthwala, alienation and consent' (2017) 33 South African Journal on Human Rights 25 at 30 where, in the context of the South African customary practice of ukuthwala, which is the mock abduction of an unmarried woman or girl by a man who intends to marry her, their research findings found that the community support the practice because, among other reasons, it helps with 'the prevention of children to be born out of wedlock'. Other causes of child marriages in the literature include poverty; a lack of education; gender discrimination; and weak and inadequate laws to address the problem; see generally C Tsiachris 'Child marriages in Southern Africa: Causes, consequences and proposals for transformation' http://www.academia.edu/23700508/ Child_marriage_in_Sub-Saharan_Africa_Causes_consequences_and_prosposals_for transformation (accessed 8 December 2017). See also paras 19 and 20 of the Joint General Recommendation/General Comment 31 of the Committee on the Elimination of Discrimination against Women (CEDAW) and 18 of the Committee on the Rights of the Child on Harmful Practices, CEDAW/C/GC/31/CRC/C/GC/18. See, eg, the CRC Committee's Concluding Observations on Malawi in July 2016 (CRC/COPSC/MWI/CO/1 para 19 (e)), where it expressed its deep concern about the harmful customs known as kupimbira and kutomera, which involve pledging, or selling a girl into forced marriage, which are still practised due to debts owed by that parents. Similar concerns were expressed when Zimbabwe reported to the CRC Committee in January 2016 (CRC/C/ZWE/CO2 para 46(a)), as also observed by Sloth-Nielsen ( $\mathrm{n} 4$ ) 540.

9 In traditional rural settings, belonging to a community entitles members to, eg, access land, dispute resolution mechanisms which are important for their socialeconomic survival in a village setup.

10 UNICEF https://data.unicef.org/wp-content/uploads/2015/11/UNICEF-Child-Marri age-Brochure-High-Single_246.pdf (accessed 11 December 2017). 
that condemn child marriage. ${ }^{11}$

Against this background, a number of Southern African countries have recently developed national initiatives aimed at ending child marriages. For example, in 2015 the Constitutional Court in Zimbabwe outlawed child marriages concluded under any law. ${ }^{12}$ In the same year, South Africa, through the South African Law Reform Commission, proposed criminalising both forced and child marriages as a result of, among others, harmful cultural practices. ${ }^{13}$ Much more recently, in 2017, Malawi amended its constitutional provision and unequivocally set the marriageable age of both women and men at 18 years. ${ }^{14}$

In view of these initiatives this article examines how the selected countries seek to address the conflict between cultural practices that lead to child marriage and the protection of children's rights. ${ }^{15}$ It also highlights both the theoretical and the practical problems that law reformers face in regulating cultural practices, as well as the gaps in the reforms that need to be addressed. The article is divided into six parts including this introduction. The second part sets the scene by highlighting the prevalence of child marriage and some cultural or religious practices that lead to child marriage in the selected countries. As background to how the domestic legal framework is responding to the conflict, the third part discusses the international and regional legal position on child marriage and cultural practices. ${ }^{16}$ The fourth part discusses the countries' specific legal responses, focusing on how they resolve the conflict in order to protect children's rights in the context of child marriage. The fifth part is a critical analysis of the different approaches to addressing child marriage. The conclusion argues that law reform initiatives are important but have to be coupled with practical ways of addressing those factors (namely, harmful practices and poverty) that lead to child marriage.

11 Eg, art 21 the African Children's Charter, art 6 the African Women's Protocol, and art 8 of the SADC Gender Protocol which all prescribe the marriageable age at 18 without exception.

12 Mudzuru \& Another v Minister of Justice, Legal and Parliamentary Affairs (CCZ 12/ 15).

13 See, eg, the South African Law Reform Commission Discussion Paper 132 (Project 138: The practice of ukuthwala), which contains the Prohibition of Forced Marriages and Child Marriages Bill, 2015.

14 Before the constitutional amendment, sec 22 of the Constitution provided that children between 15 and 18 years could marry with their parental consent.

15 State parties have been urged to take all measures necessary to eliminate harmful practices that lead to child and forced marriages, eg, the CRC Committee's recommendation on Malawi (CRC/C/OPSC/MWI/CO/1) (accessed 2 December 2017).

16 All three countries under discussion are parties to both the CRC and the African Children's Charter. 


\section{Prevalence of child marriage in the selected countries}

The prevalence of child marriage is defined as the percentage of women aged between 20-24 years who were married or in a union before they were 18 years old'. ${ }^{17}$ Plan International's 18+ Programme and Sloth-Nielsen have extensively discussed the prevalence of child marriage in Zimbabwe. ${ }^{18}$ It therefore is not necessary to repeat this. However, for purposes of this discussion it is important to highlight some indicators of child marriage in Zimbabwe as follows: Plan International's 18+ Programme estimates that, on average, one in every three girls is married before the age of $18 .^{19}$ The child population is estimated at 47 per cent, and of this number 4 per cent of girls are married before the age of 15 years, and 31 per cent of girls are married before the age of 18 years. ${ }^{20}$ Overall, Zimbabwe is ranked at 41 in the number of countries where children marry before the age of 18 years. $^{21}$

Several factors lead to child marriage in Zimbabwe. These include the persistence of deeply-entrenched social attitudes, which support early and underage marriage; ${ }^{22}$ and religious beliefs, particularly amongst the Apostolic church communities, which encourage girls between 12 and 16 years to get married in order not to sin by having sexual relations outside marriage. ${ }^{23}$ In addition, before the Mudzuru judgment (discussed later), legislation that regulates marriages in Zimbabwe perpetuated girl child marriage. ${ }^{24}$ For example, the

17 See also UNICEF 'State of the world's children 2016: A fair chance for every child', https://www.unicef.org/publications/files/UNICEF_SOWC_2016.pdf (accessed 2 December 2017); UNICEF 'The state of the world's children 2015: Reimagine the future', data.unicef.org/wp_content/upload/2015/12/sowc_2015_Summary_ and_Tables_210.pdf (accessed 8 December 2017). See also accounts by SlothNielsen (n 4) 538 .

18 Plan International In-depth review of legal and regulatory frameworks on child marriage in Zimbabwe (2016) 20 https://www.girlsnotbrides.org/wp-content/ uploads/2016/11/PLAN_18_country_report_zimbabwe_final.pdf (accessed 6 December 2017). See also UNICEF (n 17). See also Sloth-Nielsen (n 4) 538.

19 Plan International (n 18). See also UNICEF 'State of the world's children, 2016'; Zimbabwe - Child marriage around the world. Girls Not Brides, https:// www.girlsnotbrides.org/child-marriage/zimbabwe/ (accessed 8 April 2018).

20 Plan International (n 18) 8 20. See also UNICEF (n 17).

21 Plan International (n 18) 20. See also Sloth-Nielsen (n 4) 538; Panos Institute Southern Africa 'Media brief on ending child marriage in Zimbabwe' 3 http:// www.panos.org.zm/wp-content/uploads/2017/04/PSAf-ECM-Media-Brief-or-Zim babwe.pdf (accessed 2 December 2017).

22 Plan International (n 18) 23.

23 UNICEF Zimbabwe Country Office, 2014 Gender Review Report (UNICEF 2014). See also Human Rights Watch https://www.hrw.org/news/2015/12/09/endingchild-marriage-africa (accessed 11 December 2017).

24 See, eg, the Marriage Act (Cap 55:11) and the Customary Marriages Act (Cap 5:07). 
Marriage $\mathrm{Act}^{25}$ allowed girls to be married at 16 years and boys at 18 years of age. ${ }^{26}$ Furthermore, the Customary Marriage $\mathrm{Act}^{27}$ does not contain a prescribed marriageable age. Instead, this is determined by puberty, a factor generally resulting in child marriage, considering that this is attained at different age groups.

In South Africa much public attention on child marriage has been focused on the customary practice of ukuthwala. ${ }^{28}$ Ukuthwala is the mock abduction of an unmarried woman or girl for the purpose of a customary marriage. ${ }^{29}$ Unfortunately there is no data available to indicate the relationship between ukuthwala and child marriage, and the prevalence of the practice. ${ }^{30}$ Media and other reports indicate that the practice is commonly practised in the rural parts of the Eastern Cape and KwaZulu-Natal. ${ }^{31}$ However, it is important to emphasise the fact that as a legitimate traditional practice that may lead to a valid customary marriage, children who have not reached the marriageable age were not involved in the practice. ${ }^{32}$ However,

25 The Marriage Act (Cap 55:11) was enacted in 1965. Sloth-Nielsen (n 4) 544-545 thus observed that this was at a time when the international community had not agreed on a prescribed marriageable age.

26 See sec 22 of the Marriage Act (Cap 55:11).

27 The Customary Marriage Act (Cap 5:07) was enacted in 1951. The Act only regulates registered customary marriages, leaving the majority of unregistered marriages regulated by traditional customary laws.

28 See, eg, media reports: D Mabusa 'Ukuthwala: Is it culturally relative?' De Rebus 23 July 2015, www.derebus.org.za/ukuthwala-culturally-relative/ (accessed 17 November 2017); L Maduna 'Ukuthwala: The sex trafficking scandal devastating rural South Africa' Mail and Guardian 29 November 2017; A Scheepers Ukuthwala: Forced child marriages in South Africa' Women24, www.w24.co.za/Wellness/Mind/ukuthwala-forced-marriages-in-sa-20160202 (accessed 17 November 2017). See also the case of $R v$ lezile (2015 (2) SA 62 (WCC)) where a man from the Eastern Cape was convicted and sentenced to 22 years' imprisonment in 2014 after having married a girl who was 14 years old in the name of ukuthwala.

29 See general discussions on the practice in L Mwambene \& J Sloth-Nielsen 'Benign accommodation? Ukuthwala, "forced marriage" and the South African Children's Act' (2011) 11 African Human Rights Law Journal 1; Mwambene \& Kruuse (n 8); and DS Koyana \& JC Bekker 'The indomitable ukuthwala custom' (2007) De Jure 139-144.

30 The prevalence of ukuthwala can be depicted from what Koyana \& Bekker (n 29) 139 note: 'From the enquiries that we made and on the basis of our own observations we are assured that the twala custom is still widely practised in Nguni communities.' More recently, a Mwambene and Kruuse field study (n 8) conducted in September 2015 and April 2016 in Engcobo, where the Jezile case originated, revealed that ukuthwala was still practised and was a respected cultural practice that is strongly linked to child marriage.

31 'The community of KwaCele, near Lusikisiki, has promised to end the practice of ukuthwala' Media 24.com 24 March 2011; 'Salvation Army calls for end to ukuthwala' IOLNews 7 December 2015; 'Ukuthwala:The sex trafficking scandal devastating rural South Africa' Mail and Guardian 29 November 2017; and 'Hawks rescue E girl from ukuthwala' @SABCNewsOnline 25 December 2017.

32 Mwambene \& Sloth-Nielsen (n 29); Mwambene \& Kruuse (n 8) 25-45. See also recounts of the practice by the expert witness in $R v$ Jezile ( $\mathrm{n} 28$ ). There are different reasons for ukuthwala: the fact that it allows a girl or woman to get married to a man of her choice; it forces the father to enter into marriage negotiations of his daughter's marriage where he may have not wanted to; and 
the fact that the marriageable age according to custom is the age of puberty, which is usually attained before the age of 18 years, means that ukuthwala leads to child marriage. ${ }^{33}$ In addition, the laws that govern customary marriages, namely, the Recognition of Customary Marriage Act (RCMA), ${ }^{34}$ read together with the Marriages $\mathrm{Act}^{35}$ which allows minors to get married provided they have the necessary consent, arguably may be contributors to the challenge to ending child marriages in South Africa. ${ }^{36}$

Statistics regarding child marriage in South Africa estimate that 6 per cent of girls marry before the age of 18 years, and 1 per cent by the age of 15 years. ${ }^{37}$ This figure is far lower compared to that of Zimbabwe (4 per cent marrying by the age of 15, and 31 per cent girls before 18 years) and Malawi (12 per cent marrying by the age of 15 , and 50 per cent before the age 18 years). ${ }^{38}$ However, the fact remains that child marriage in South Africa is a reality, which is a threat to the protection of children's rights. ${ }^{39}$ For example, in 2013 Statistics South Africa reported that 14 grooms and 172 brides, under the age of 18 , were married according to civil law. ${ }^{40}$ In the same year nine grooms and 79 brides under the age of 18 were married according to customary law. ${ }^{41}$ In addition, the 2016 Community Survey results, also released by Statistics South Africa, indicate that more than 91000 South African girls between the ages of 12 and 17 years are either married, divorced, widowed or living with a partner. ${ }^{42}$

helps to get women to have children within a marriage wedlock.

33 It is general knowledge that puberty can be reached at different ages, even as low as between 9 and 12 years of age.

34 Recognition of Customary Marriages Act 108 of 1998, which entered into force on 15 November 2000.

35 Marriage Act 25 of 1961.

36 Secs 3(a) and (b) of the RCMA read with sec 25 of the Marriage Act allows both boys and girls of under 18 to get married provided they have the consent of a parent, guardian, or Commissioner of Welfare/Minister of Home Affairs. In particular, sec 3(a) of the RCMA provides that '[i]f either of the prospective spouses is a minor, both his or her parents, or if he or she has no parents, his or her legal guardian must consent to the marriage'. Sec 3(b) provides: 'If the consent of the parent or legal guardians cannot be obtained, section 25 of the Marriage Act, 1961 applies.' However, it is interesting to note that while all minors must obtain the consent of the Minister of Home Affairs in terms of the RCMA, girls above the age of 15 do not need ministerial consent in terms of sec 26 of the Marriage Act. This differentiation of minors concluding marriages under the Marriage Act and RCMA may arguably be challenged on constitutional grounds.

37 UNICEF (n 17).

38 UNICEF (n 6).

39 UNICEF (n 17).

40 Statistics South Africa 'Marriages and divorces 2013' www.statssa.gv.za/ publications/p0307/p03072013.pdf (accessed 17 December 2017).

41 As above.

42 As above. Of this figure, KwaZulu-Natal ranks the highest with 25205 and Gauteng with 15929 young girls married before the age of 18 years. 
Moreover, the 2016 UNICEF data revealed a rise in child marriages in South Africa. ${ }^{43}$

By comparison, Malawi is one of the top ten countries with the highest rates of child marriage in Africa. ${ }^{44}$ Reports indicate that in 2010, approximately 50 per cent of women aged 20 to 24 years were married before the age of 18 years. ${ }^{45}$ Despite this alarming figure, data reveals very little change in the prevalence of child marriage since 2000. Studies show that child marriage in Malawi is also higher than the regional average for sub-Saharan Africa, which is at 37 per cent. $^{46}$ Four per cent of the population marry before their fifteenth birthday and 24 per cent of the population before their nineteenth birthday. ${ }^{47}$ Further, UNICEF statistics revealed that Malawi has the eleventh highest child marriage rate in the world, with nearly one in two girls married before the age of 18 years. ${ }^{48}$ It is also estimated that between 2010 and 2013, 27612 girls in primary school and 4053 high school girls dropped out of school because of forced marriage. ${ }^{49}$

The 2005 Malawi Human Rights Commission study found that child and forced marriages are deeply entrenched in Malawi's traditions and patriarchal cultures, which encourage early sexual initiation and marriage. ${ }^{50}$ Marriage is also regarded as a means of protecting girls who fall pregnant from embarrassing the family honour. ${ }^{51}$ In addition, the prevalence of child marriage in Malawi is also linked to the lack of education of girls and women. The latest figures show that nearly 65 per cent of women in Malawi with no formal education are child

43 UNICEF 'A profile of child marriage in Africa' https://data.unicef.org/resources/aprofile-of-child-marriage-in-africa/ (accessed 2 December 2017).

44 Girls Not Brides, 'Child marriages around the world: Malawi' https:// www.girlsnotbrides.org/child-marriage/malawi/ (accessed 2 December 2017).

45 Human Rights Watch 2014 'Child marriage in Malawi' https://www.hrw.org/ report/2014/03/06/ive-never-experienced-happiness/child-marriage-malawi

(accessed 8 December 2017). Malawi also remains one of the countries with a high HIV infection rate. The National AIDS Commission (NAC) estimated that the total HIV infection rate is 898888 of which adult women over the age of 15 years represented 53\% (CEDAW, Sixth Report, 2008). Approximately 30000 out of 100000 new infections have been attributed to mother-to-child transmission, including mothers below the age of 18 years.

46 S White 'No ifs or buts: Child marriage needs to be abolished in Malawi once and for all' 2015, http://edition.cnn.com/2015/03/03/africa/seodi-white-child-marri age/index.html (accessed 19 December 2017).

47 Human Rights Watch (n 45). See also White (n 46).

48 United Nations International Children Education Fund 'Ending child marriage: Progress and prospects' UNICEF, New York 2014, https://www.unicef.org/media/ files/Child_Marriage_Report_7_17_LR.pdf (accessed 2 December 2017).

49 Human Rights Watch (n 45).

50 See the general discussion on the different cultural practices by the Malawi Human Rights Commission 'Cultural practices and their impact on the enjoyment of human rights, particularly the rights of women and children in Malawi' 2005, https://searchworks.stanford.edu/view/6842923 (accessed 19 December 2017).

51 Human Rights Watch (n 45). 
brides, compared to 5 per cent of women who attended secondary school or higher education. ${ }^{52}$

\section{International context on child marriage and cultural practices}

As pointed out, Zimbabwe, South Africa and Malawi are state parties to major international instruments for the protection of children's rights. ${ }^{53}$ Several international instruments set standards for the protection of children's rights as follows: As far as child marriage is concered, the Joint General Recommendation/General Comment 31 of the Committee on the Elimination of Discrimination against Women (CEDAW Committee) and General Comment 18 of the Committee on the Rights of the Child on Harmful Practices (2014) ${ }^{54}$ have been lauded as 'comprehensively spell[ing] out the position of these two Committees on the topic of child, early and forced marriage' 55 These unequivocally regard child marriage as forced marriage. ${ }^{56}$ Examples of forced marriage, according to the General Recommendation/General Comment include situations where one or both parties to a marriage have not personally expressed their full and free consent through, for example, marrying girls too young; the marriage of girls by armed forces in conflict situations; the payment of dowry and bride price which increases the vulnerability of women and girls to violence; situations where families will agree to the temporary marriage of their daughter in exchange for financial gain; and allowing a rapist to escape criminal sanction by marrying the victim. ${ }^{57}$ Sloth-Nielsen and Kachika have highlighted these examples to strengthen advocacy to eradicate forced child marriages in all

52 Girls Not Brides 2015 'Ending child marriage in Africa' https://www. girlsnotbrides.org/wp-content/uploads/2015/02/Child-marriage-in-Africa-A-briefby-Girls-Not-Brides.pdf (accessed 19 December 2017).

53 By ratification, these states undertook a legal obligation to implement the rights recognised in the particular treaty. In addition, these states undertake to put in place domestic measures and legislation compatible with their treaty obligations. They also commit to submitting regular reports on how the rights are being implemented to the monitoring committee set up under the treaty. See also similar observations by Sloth-Nielsen (n 4).

$54 \mathrm{CRC/C/GC/18} \mathrm{(2014).} \mathrm{See} \mathrm{also} \mathrm{similar} \mathrm{observations} \mathrm{by} \mathrm{Sloth-Nielsen} \mathrm{(n} \mathrm{4)} 538$.

55 See, generally, discussed in the Plan18+ Programme (n 18) 13, L Mwambene \& O Mawodza 'Children's rights standards and child marriage in Malawi' (2017) African Studies Quarterly, http://www.africa.ufl.edu/asq/v17/v17i3a2.pdf; SlothNielsen (n 4) 538.

56 Para 20 Joint General Recommendation/General Comment 31 of the Committee on the Elimination of Discrimination against Women CEDAW and 18 of the Committee on the Rights of the Child on Harmful Practices (2014). See also cited in Mwambene \& Mawodza (n 55).

57 Para 23, Joint General Recommendation/General Comment 31 (n 56) of the Committee on the Elimination of Discrimination against Women CEDAW and 18 of the Committee on the Rights of the Child on Harmful Practices (2014). 
contexts. $^{58}$ Consequently, the General Recommendation/General Comment places an obligation on state parties to establish legal structures to ensure that harmful practices are promptly and impartially investigated and that effective remedies are provided to those who have been harmed. ${ }^{59}$

The General Recommendation/General Comment sets an 'absolute ceiling for minimum age at 16 , meaning that states parties will not be justified for any reason whatsoever to accept marriages where a party is lower than this age' ${ }^{60}$ This is a standard lower than that in article 21(2) of the African Charter on the Rights and Welfare of the Child (African Children's Charter), and article 6(b) of the Protocol to the African Charter on Human and Peoples' Rights on the Rights of Women in Africa (African Women's Protocol), that unequivocally set the marriageable age at 18 .

In addition, numerous other General Comments and Recommendations of the Convention on the Rights of the Child $(\mathrm{CRC})$, the Convention on the Elimination of All Forms of Discrimination against Women (CEDAW) and the Human Rights Committee are relevant to this discussion. These include the CRC Committee's General Comment 3: HIV/AIDS and the Rights of the Child (2003) that addresses child marriage by reiterating that a female child often is subjected to harmful traditional practices that violate her rights and make her more vulnerable. ${ }^{61}$ The CRC Committee's General Comment 13: The Rights of the Child to Freedom from all Forms of Violence (2011) depicts forced and early marriage as harmful practices, bringing both within the ambit of violence against children. ${ }^{62}$ More importantly, the CRC Committee's General Comment 13 regards the failure to adopt or revise legislation and other provisions, and the inadequate implementation of the laws as a breach of CRC, and thus a violation of children's rights. ${ }^{63}$

Furthermore, the CEDAW Committee's General Recommendation 24: Women and Health (1999) reminds state parties of article 16(2) of CEDAW, which proscribes the betrothal and marriage of children, an important factor in preventing the physical and emotional harm arising from early childbirth. ${ }^{64}$ Moreover, the Concluding Observations of the International Covenant on Economic, Social and Cultural Rights (ICESCR) have elaborated further concerns regarding

58 J Sloth-Nielsen \& T Kachika 'Applicable international and regional law and policy: Child, early and forced marriage' submitted to Plan+18 Programme.

59 Paras 31-36, Joint General Recommendation/General Comment 31 (n 56) and 18 of the Committee on the Rights of the Child on Harmful Practices (2014).

60 Sloth-Nielsen \& Kachika (n 58) 14.

61 Para 6 CRC General Comment 3 on HIV/AIDS and the Rights of the Child 2003.

62 CRC Committee General Comment 13 on the Right of the Child to Freedom from All Forms of Violence (2011) para 27.

63 See observations by Sloth-Nielsen \& Kachika (n 58).

64 Paras 15(d) and 28, CEDAW Committee General Recommendation 24: Women and Health (1999). 
child marriage, such as the differences in marriageable age of males and females in the Marriage Act, and recommended that the state party should harmonise its laws so that the minimum age for both girls and boys reflect international standards. ${ }^{65}$

Additionally, few other examples of international instruments are implicated, including the Universal Declaration of Human Rights (Universal Declaration); ${ }^{66} \mathrm{CRC}^{67}$ the CRC Optional Protocol on the Sale of Children, Child Prostitution and Child Pornography (2002); ${ }^{68}$ the Convention on the Elimination of All Forms of Discrimination against Women (1979); ${ }^{69}$ the International Covenant on Civil and Political Rights (ICCPR); ${ }^{70}$ the Convention on the Consent to Marriage, Minimum age for Marriage and Registration of Marriage (1962) $;{ }^{71}$ the UN Protocol to Prevent, Suppress and Punish Trafficking in Persons Especially Women and Children, supplementing the United Nations Convention against Transnational Organised Crime (2000); ${ }^{72}$ the African Children's Charter; ${ }^{73}$ the African Youth Charter (2006); ${ }^{74}$ the African Women's Protocol; ${ }^{75}$ and the Southern African Development Community (SADC) Protocol on Gender and Development (2008). ${ }^{76}$ Of special relevance is the 2014 Declaration by the African Union (AU), urging all member states to set the

65 ICSECR Concluding comments, South Africa, E/C.12/ZAF/CO/1 2018 paras 52-53. Art 10 of ICESCR provides that marriage shall be entered with the free consent of the intending parties.

66 See, eg, art 16(2) of the Universal Declaration.

67 See arts 2, 3, 6, 12, 17, 19, 24, 28, 31, 32, 34, 35 \& 39 of CRC. CRC was ratified by Zimbabwe in 1990; by South Africa in 1995; and by Malawi in 1991.

68 See art 2(a); ratified by Zimbabwe in 2012; by South Africa in 2003; and by Malawi in 2009.

69 See arts 2(f), 5(a) and 16(2) of CEDAW, ratified by Zimbabwe in 1991; by South Africa in 1995; by Malawi in 1987, initially with reservations on art 5, which carries the obligation for state parties to take all appropriate measures to modify the social and cultural patterns of conduct of men and women, with a view to achieving the elimination of prejudices and customary and all other practices which are based on the idea of the inferiority or superiority of either of the sexes or on stereotyped roles for men and women. The reservation was withdrawn on 24 October 1991.

70 Ratified by Zimbabwe in 1991; by South Africa in 1998; Malawi has not yet ratified it.

71 Ratified by Zimbabwe in 1994; by South Africa in 1993; Malawi has not yet ratified it.

72 Ratified by Zimbabwe in 2013; by South Africa in 2004; by Malawi in 2005.

73 Ratified by Zimbabwe in 1995; by South Africa in 2000; and by Malawi in 1999. Art 21 of the African Children's Charter obliges 'states parties to the present Charter to take all appropriate measures to eliminate harmful, social and cultural practices affecting the welfare, dignity, normal growth and development of the child, in particular (a) those practices prejudicial to the health or life of the child and (b) those customs and practices discriminatory on the grounds of sex or other status'.

74 Ratified by Zimbabwe in 2009; by South Africa in 2009; and by Malawi in 2010.

75 Ratified by Zimbabwe in 2008; by South Africa in 2004; and by Malawi 2005.

76 Ratified by Zimbabwe in 2008; South Africa not ratified; and by Malawi in 2013. 
minimum age for marriage at 18 years for both boys and girls. ${ }^{77}$ It is also important to highlight that the need to end child marriage and other harmful practices affecting women and girls is also embedded in Agenda 2063, the AU's 50-year vision for the development of the continent, to end child marriages. ${ }^{78}$

The most recent regional standard in addressing child marriage on the African continent is the Joint General Comment of the African Commission on Human and Peoples' Rights (African Commission) and the African Committee of Experts on the Rights and Welfare of the Child (African Children's Committee) on Ending Child Marriage (2017). ${ }^{79}$ It unequivocally sets the marriageable age at 18 , and defines child marriage as 'a marriage in which either one of the parties or both is or was a child under the age of 18 at the time of the union'.80 The position adopted by this Joint General Comment is to be applauded. It has effectively laid down a higher standard, reviewing all legislation that allows the majority age to be attained through marriage. 81

The following key principles may be drawn from these international instruments, many of which articulate the need for a uniform marriage age, and also emphasise the importance of free and full consent to marriage as a means of protecting the rights of women and girls in the following ways. ${ }^{82}$ First, these instruments generally prohibit child marriage and the betrothal of both girls and boys. ${ }^{83}$ To this end, they require that state parties take effective action, including legislation to specify the minimum age of marriage to be 18 years. $^{84}$

77 Addis Ababa Declaration on Ending Child Marriage in Africa, http:// srsg.violenceagainstchildren.org/sites/default/files/documents/docs/ACERWC-Dec laration-on-Ending-Child-Marriage-in-Africa.pdf (accessed 10 December 2017).

78 'Agenda 2063: The Africa We Want', http://www.un.org/en/africa/osaa/pdf/au/ agenda2063-first10yearimplementation.pdf (accessed 10 December 2017).

79 'Joint General Comment of the African Commission on Human and Peoples' Rights (ACHPR) and the African Committee of Experts on the Rights and Welfare of the Child (ACERWC) on Ending Child Marriage' (2017) http://www.achpr.org/ files/news/2018/01/d321/joint_gc_acerwc_achpr_ending_child_marriage_eng.pdf (accessed 22 October 2018).

80 Joint General Comment (n 79) para 6.

81 See, eg, sec 24(2) of the South African Marriage Act 1961 where a minor effectively becomes a major upon concluding a valid marriage.

82 See, eg, art 16(2) of the Universal Declaration; art 16(2) of CEDAW; and art 6 of the African Women's Protocol.

83 Art 21(2) of the African Children's Charter declares that 'child marriage and the betrothal of girls and boys shall be prohibited and effective action, including legislation, shall be taken to specify the minimum age of marriage to be 18 years and make registration of all marriages in an official registry compulsory'. Similar prescriptions are to be found in art 16 (2) of CEDAW; paras 36-39 of CEDAW Committee General Recommendation 21: Equality in Marriage and Family Relations (1994); paras 15(d) and 28 of CEDAW Committee General Recommendation 24: Women and Health (1999).

84 See, eg, art 16(2) of the Universal Declaration; art 21(2) of the African Children's Charter; art 6 of the African Women's Protocol; art 10 of ICSECR; arts 1, 2 \& 3 of the Marriage Convention. 
They also require state parties to make the registration of marriages compulsory. ${ }^{85}$ As rightly observed,

this is an important obligation for states parties to ensure that children are not getting married below the internationally accepted minimum age of marriage and that systematic registration of marriages is used to ensure that minimum marriage age is enforced. ${ }^{86}$

In addition, these international instruments prescribe that spouses enjoy equal rights and are regarded as equal partners in marriage. ${ }^{87}$ Consequently, they oblige state parties to enact appropriate national legislative measures to guarantee that no marriage takes place without the free and full consent of both parties. ${ }^{88}$ The ICCPR Human Rights Committee's General Comment 28 elaborates on the obligation of state parties to eradicate harmful cultural practices that lead to inequality between men and women as follows: ${ }^{89}$

Inequality in the enjoyment of rights by women is deeply embedded in tradition, history and culture, including religious attitudes ... States parties should ensure that traditional, historical, religious and cultural attitudes are not used to justify violations of women's rights to equality before the law and to equal enjoyment of all Covenant rights.

Particularly focusing on the rights of the girl child mostly affected by child marriage, international standards require state parties to take appropriate measures with a view to abolishing traditional practices prejudicial to the health of children. ${ }^{90}$ Thus, early marriage is now understood to be harmful to the health of children. ${ }^{91}$

To sum up, all the international standards stipulate that where cultural practices hinder or stand in the way of children's rights, the cultural practice must give way. ${ }^{92}$ The following discussion will assess whether this happens in practice.

85 Art 3 Marriage Convention; art 8(2) SADC Protocol on Gender and Development 2008.

86 Sloth-Nielsen \& Kachika (n 58).

87 Art 6 African Women's Protocol.

88 Art 1(c)(i) of the Abolition of Slavery Convention that equates any marriage that is forced upon a girl by her guardian to slavery. See also art 23(3) of ICCPR; art $16(2)$ of the Universal Declaration; art 6 of the African Women's Protocol.

89 CCPR Committee General Comment 28, http://www.unhchr.cr (accessed 2 December 2017).

90 See, eg, art 24 of CRC.

91 See, eg, art 24 of CRC; art 23 of the African Youth Charter.

92 See, eg, arts 2(f) and 5(a) of CEDAW. See also Mwambene \& Mawodza (n 55) 33. 


\section{Recent legal responses to child marriage and children's rights}

\subsection{Zimbabwe}

In response to its obligations, Zimbabwe passed several Acts relevant to addressing child marriage. Principal among this legal framework is the 2013 Constitution. ${ }^{93}$ Sub-sections 78(1) and (2) of the Constitution set the minimum age for marriage at 18 years, and prohibit forced marriage. ${ }^{94}$ These sub-sections further require the state to take appropriate measures to ensure that no marriage is entered into without the free and full consent of the intended spouses. ${ }^{95}$ More relevant to addressing cultural practices, such as kuzvarira, where a girl is forced to enter into a union with her sister's husband for the purpose of producing children, the Constitution requires the state to take measures to ensure that children are not pledged in marriage. ${ }^{96}$

Apart from the Constitution, the Customary Marriage Act (Cap 5:07), which regulates registered customary marriages in Zimbabwe, is also relevant. ${ }^{97}$ Section 11 of the Act prohibits the pledging of girls in marriage. However, the Act does not stipulate the prescribed age of marriage. The Plan+18 Programme observes the inadequacy of this provision in addressing child marriage since puberty, according to custom, is a marriageable age. ${ }^{98}$

A more recent and celebrated attempt to address child marriage in Zimbabwe is found in the Constitutional Court case of Mudzuru. ${ }^{99}$ In Mudzuru two young women, aged 18 and 19, brought the case to the Constitutional Court respectively, in terms of section 85(1) of the Constitution of Zimbabwe. ${ }^{100}$ The two applicants advocated the protection of children's rights, particularly girl children who are

93 Constitution of the Republic of Zimbabwe Amendment 20 of 2013. It entered into force on 20 May 2013.

94 Sec 78(2) provides that ' $\mathrm{n}] \mathrm{o}$ person may be compelled to enter into marriage against their will'. This is consistent with art 21 of the African Children's Charter and art 6 of the African Women's Protocol which sets 18 as the minimum age of marriage, and arts 10(1), 16(2) and 23 of CESCR, CEDAW and ICCPR, which require the consent of the parties to the marriage.

95 Sec 26(a) of the Constitution.

96 Sec 26(b) of the Constitution.

97 It therefore is assumed that all unregistered customary marriages in Zimbabwe are regulated by traditional customary rules which, coupled with poverty, predispose girls to child marriage.

98 Plan International (n 18) 27.

99 Loveness Mudzuru and Ruvimbo Tsopodzi v Minister of Justice, Legal and Parliamentary Affairs, Minister of Women Affairs, Gender and Community Development, Attorney-General of Zimbabwe Application 79/14 CC 12/2015.

$100 \mathrm{Sec} 85(1)$ of the Constitution of the Republic of Zimbabwe Amendment states that '[a]ny of the following persons, namely, (a) any person acting in their own personal interest; (b) any person acting on behalf of another person who cannot act for themselves; (c) any person acting as a member, or in the interest of a group or class of persons; (d) any person acting in the public interest; (e) any 
subjected to the challenges of child marriage. The Court had to decide whether the effect of section $78(1)^{101}$ of the Zimbabwean Constitution is to set 18 years as the minimum age of marriage in Zimbabwe. In addition, the Court had to determine whether section 22(1) of the Marriage Act, which prohibited the marriage of a boy under the age of 18 and a girl under the age of 16 years, except with the written permission of the Minister of Justice, ${ }^{102}$ and the Customary Marriages Act ${ }^{103}$ with no predetermined age of marriage was constitutional.

The applicants argued that, on a broad and generous and purposive interpretation of section 78(1) as read with section 81(1) of the new Constitution, the age of 18 had become the minimum age for marriage in Zimbabwe. ${ }^{104}$ They argued that section 78(1) of the Constitution could not be subjected to a strict, narrow and literal interpretation to determine its meaning if regard is had to the contents of similar provisions on marriage and family rights found in international human rights instruments from which section 78(1) derives inspiration. ${ }^{105}$ Hence, the main argument by the applicants was that, since a 'child' now is defined by section 81(1) of the Constitution to mean a girl and a boy under the age of 18 years, no child has the capacity to enter into a valid marriage in Zimbabwe since the entry into force of sub-sections 78(1) and 81(1) of the new Constitution on 22 May 2013. They further argued that section 22(1) of the Marriage Act or any other law which authorises a girl under the age of 18 years to marry, infringed the fundamental right of the girl child to equal treatment before the law enshrined in section 81(1)(a) of the Constitution. ${ }^{106}$ The argument was that section 22(1) of the Marriage Act exposed the girl child to the horrific consequences of early marriage, which are the very injuries against which the fundamental rights are intended to protect every child. ${ }^{107}$

The Constitutional Court ruled that section $78(1)$ of the Constitution sets 18 as the minimum age of marriage. ${ }^{108}$ The Court declared section 22(1) of the Marriage Act, or any customary and religious practices authorising any child to be married before the age

association acting in the interest of its members; is entitled to approach a court, alleging that a fundamental right or freedom enshrined in this Chapter has been, is being or is likely to be infringed and the court may grant appropriate relief, including a declaration of rights and an award of compensation'.

$101 \mathrm{Sec}$ 78(1) of the Constitution of the Republic of Zimbabwe Amendment deals with marriage rights and states that '[e]very person who has attained the age of eighteen years has the right to found a family'.

102 Sec 22(1) of the Marriage Act [Chapter 5:11] states that a girl who has obtained the age of sixteen years is capable of contracting a valid marriage.

103 Marriage Act [Chapter 5:07].

104 Mudzuru (n 99) 3.

105 As above.

$106 \mathrm{Sec} 81(1)(\mathrm{a})$ of the Constitution provides that '[e]very child ... has the right to equal treatment before the law, including the right to be heard'.

107 Mudzuru (n 99) 4.

108 Mudzuru 1. 
of 18 , to be invalid to the extent of its inconsistency with the Constitution. ${ }^{109}$ In addition to that, the Court also concluded that with effect from 20 January 2016, no person, male or female, may enter into any marriage, including one arising from religion or religious rites, before attaining the age of 18 years. ${ }^{110}$ As the Court observed, this judgment seems to be

in line with the goals of social justice at the centre of international human rights standards requiring Zimbabwe to take appropriate legislative measures, including constitutional provisions, to modify or abolish existing laws, customs inconsistent with the rights of the child.

The Mudzuru decision, just as the international legal standards on the protection of children's rights discussed above, addresses the tension between children's rights and customary practices that lead to child marriage by giving primacy to children's rights. The Constitutional Court further observed that section $78(1)$ of the Constitution was clear that it

permits of no exception for religion, customs or cultural practices that permits child marriage. When read together with section $81(1)$, section 78(1) has effectively reviewed local practices and customs on marriage. ${ }^{112}$

More importantly, as Sloth-Nielsen and Hove rightly observe,

the judgment sets an important standard for the other 47 state parties to the Charter in so far as it delineates the expectation for domestic statues on marriage and child protection law. Further, it accords primacy to treaty obligations, which were voluntarily undertaken. ${ }^{113}$

However, the Constitutional Court's decision might be paper law, with no legal effect on child marriage in Zimbabwe. It did not prescribe measures to ensure that children are protected from child marriage. For example, in addition to outlawing child marriage, the Constitutional Court could have prescribed a reasonable time for Parliament to amend laws that allow child marriage to be implemented. ${ }^{114}$

\subsection{South Africa}

South Africa, by prescribing the marriageable age to be 18 years for both girls and boys under the Recognition of Customary Marriages Act, ${ }^{113}$ arguably has outlawed all customary marriages of children

109 Mudzuru 49.

110 Mudzuru 50.

111 Mudzuru 49.

112 As above.

113 J Sloth-Nielsen \& K Hove 'Mudzuru and Another $v$ Minister of Justice, Legal and Parliamentary Affairs \& 2 Others: A review' (2015) 15 African Human Rights Law Journal 554 at 563.

114 Mudzuru (n 99) 55.

$115 \mathrm{Sec}$ 3(1) of the Recognition of Customary Marriages Act 120 of 1998. 
under the age of 18 years. ${ }^{116}$ However, the Recognition of Customary Marriages Act, read with the Marriage Act, allows persons below the age of 18 to get married provided they have the necessary consent. $^{117}$ This position sends conflicting messages in respect of efforts to end child marriages linked to customary practices in South Africa. In addition, statutory rape, namely, consensual sex with a child below the age of 16 years, assault, rape and kidnapping, all implicit in the modern-day practice of ukuthwala, are criminally sanctioned in terms of the Sexual Offences Act. ${ }^{118}$

More recently, the South African Law Reform Commission proposed the Prohibition of Forced Marriages and Child Marriages Bill, 2015 which seeks to outlaw and criminalise all forced and child marriages as a result of, among other factors, ukuthwala. ${ }^{119}$ The Prohibition of Forced Marriages and Child Marriages Bill is a response to concerns expressed from the Gender Directorate. ${ }^{120}$ The Gender Directorate argued that children affected by ukuthwala, resulting in their rights to personal safety and well-being being violated, are at risk of lifelong developmental burdens, including HIV infection and other physical, emotional and social problems. ${ }^{121}$ The Directorate also stressed that South African values, beliefs and practices must be consistent with the Constitution, which specifically guarantees the rights of children. ${ }^{122}$ Concern was particularly raised about the impact of ukuthwala on the girl child and the appropriateness and adequacy of current laws on ukuthwala, and whether the laws uphold the human rights of the girl child, taking into consideration the principle of the best interests of the child. ${ }^{123}$

With this end in view, the Law Reform Commission produced a report on ukuthwala which culminated in the Prohibition Bill. ${ }^{124}$ As pointed out earlier, the Prohibition Bill is aimed at criminalising forced marriages and child marriages, including those as a result of ukuthwala. If the Prohibition Bill becomes law, it will be the first time that such child marriages will be criminalised in South Africa. ${ }^{125}$ Besides criminalising forced marriages and child marriages, the Prohibition Bill will give effect to international law and the

$116 \mathrm{Eg}$, sec 3(1) of the RCMA sets the marriageable age for both a man and woman at 18 years.

117 See, in particular, sec 3(a) of the Recognition of Customary Marriages Act and sec 25 of the Marriage Act.

118 In Jezile $v R$ the appellant was convicted, among other charges, of rape which is an offence provided for in the Sexual Offences Act.

119 Contained in the South African Law Reform Commission Discussion Paper 132 (Project 138: The practice of ukuthwala).

120 The Gender Directorate is part of the Department of Justice and Constitutional Development.

121 South African Law Reform Commission (n 122).

122 As above.

123 South African Law Reform Commission (n 122) 1 para 1.1.

124 South African Law Reform Commission (n 122).

125 See, eg, the Trafficking Act regarding forced marriages. 
constitutional values of human dignity. It will require that marriages are entered into freely and without any form of coercion, and will provide for the prosecution and penalties of persons who commit offences. ${ }^{126}$ At the same time, the Prohibition Bill has a number of shortcomings in that it does not set out the marriageable age of 18 years without exceptions. The Prohibition Bill also does not repeal provisions that allow children to get married in both the Marriage Act and the Recognition of Customary Marriages Act. Finally, the Prohibition Bill does not amend provisions in the Children's Act that are vague in relation to the minimum age of marriage and the betrothal of children.

\subsection{Malawi}

In discussing Malawi's recent legal response to child marriage, the starting point is the constitutional amendment of 14 February 2017. Parliament voted to remove a constitutional provision allowing children to marry with the consent of their parents. ${ }^{127}$ The protracted process to this constitutional amendment saw different stakeholders making several recommendations on the Malawi Law Commission's proposal to review the Malawian Constitution. ${ }^{128}$ Of particular relevance in regard to addressing child marriage is the proposal that the age of childhood be raised from 16 to 18 years of age so as to harmonise the constitutional provision with international legal standards, including those of CRC. ${ }^{129}$ The Malawi Law Commission in its submission accordingly recommended to the Ministry of Justice and Constitutional Affairs that the age of majority in section 23 of the Malawian Constitution be raised to 18 years.

Reverting to the current position, the celebrated constitutional amendment, setting the majority and marriageable age at 18, became law in April 2017.130 At the domestic level this amendment has harmonised the Constitution which is the supreme law of the land, with the Marriage, Divorce and Family Relations Act, 2015 which categorically sets the minimum age of marriage at 18 years. ${ }^{131}$ The constitutional amendment, therefore, closed the legal gap created by allowing child marriages in Malawi. In addition, Mwambene and Mawodza identify several other provisions in the Constitution that may be used to address child marriages linked to cultural practices. ${ }^{132}$

126 See sec 2 of the Prohibition Bill.

127 Sec 22(6), read together with sec 23 of the Constitution allowed the marriages of persons below 18 years; see general discussions by Mwambene \& Mawodza (n 55).

128 See, eg, the Ministry of Gender, Children and Community Development in 2004 Comprehensive Position Paper.

129 Sixth Periodic Report CEDAW, 2008.

130 Constitutional Amendment Act 36 of 2017.

131 Sec 14 as read with sec 2 of the Marriage, Divorce and Family Relations Act, 2015.

132 Mwambene \& Mawodza (n 55). 
However, seen as a position conflicting with the above, the Child Care, Protection and Justice Act, 2011, which is dedicated to the protection of children's rights in Malawi, defines a child as a person below the age of 16 years. ${ }^{133}$ While the constitutional amendment constitutes a critical measure to reduce child marriages, there is a potential risk that the definition of the child in this Children's Act may continue to undermine any efforts to the protection of children's rights in the context of child marriages.

Apart from the Constitution, sections $80,{ }^{134} 81,13582$ and 83 of the Child Care, Protection and Justice Act (Children's Act) ${ }^{136}$ are relevant in addressing child marriage in Malawi. Given the fact that there are a number of harmful practices ${ }^{137}$ that infringe on children's rights, the Children's Act prohibits anyone from subjecting a 'child to a social or customary practice that is harmful to the health or general development of the child' ${ }^{138}$ For instance, forcing a child into marriage or forcing a child to be betrothed is specifically prohibited by section 81 of the Children's Act. Related to the above are some cultural practices where a child is pledged to obtain a debt (kupimbira), ${ }^{139}$ mostly practised in the Karonga and Chitipa districts. ${ }^{140}$ As previously observed, these provisions target harmful cultural practices that lead to child marriage and make it a criminal offence for anyone to contravene these provisions. ${ }^{141}$

In a similar vein, the Marriage, Divorce and Family Relations Act, 2015 also explicitly states that a marriage to someone who is below the age of 18 is punishable with imprisonment. ${ }^{142}$ Furthermore, the Marriage Act, read with section 22 of the constitutional amendment, defines a child as any person below the age of 18 and fixes the marriageable age at 18 years. ${ }^{143}$ Additional legal initiatives to address child marriage are to be found in the National Registration Act, 2009

133 Sec 2 Child Care, Protection and Justice Act, 2011.

$134 \mathrm{Sec} 80$ provides that '[n]o person shall subject a child to a social or customary practice that is harmful to the health or general development of the child'.

135 Sec 81 provides that '[n]o person shall force a child into marriage; or force a child to be betrothed'.

136 The Child Care, Protection and Justice Children's Act, 2010, in force from 1 September 2011.

137 MHRC Cultural practices and their impact on the enjoyment of human rights, particularly women and children (2005) 18. See also L Mwambene 'Marriage under African customary law in the face of the Bill of Rights and international human rights standards in Malawi' (2011) 11 African Human Rights Law Journal 78.

138 Sec 80 Children's Act.

139 According to this custom, young girls are often held in perpetual bondage and are often subjected to abuse.

140 CEDAW report.

141 Mwambene \& Mawodza (n 55) 29-30.

142 Marriage, Divorce and Family Relations Act, 2015.

$143 \mathrm{Sec} 14$ of the Marriage, Divorce and Family Relations Act provides that '[s]ubject to section 22 of the Constitution, two persons of the opposite sex who are both not under the age of eighteen years, and are of sound mind, may enter into marriage with each other'. 
which creates a legal framework for universal birth registration. ${ }^{144}$ The National Registration Act has far-reaching consequences for child marriage in Malawi due to the existing low birth registration rate, estimated to be around 3 per cent. ${ }^{145}$ Birth registration can reduce child marriage as it serves as proof of age of spouses intending to get married.

\section{Analysis: Future considerations}

The exploration of the above law reform initiatives reveals two main trends regarding how to address child marriage and protect children's rights. These include the use of international standards and the criminalisation of child marriages.

\subsection{International standards}

There is overwhelming evidence of the use of international standards in addressing child marriage by the selected countries. ${ }^{146}$ This is illustrated by the finding of the Constitutional Court in the Mudzuru case that, by ratifying CRC and the African Children's Charter,

Zimbabwe expressed its commitment to take all appropriate measures, including legislative, to protect and enforce the rights of the child as enshrined in the relevant conventions to ensure that they are enjoyed in practice.

More relevant to its decision of abolishing child marriages, the Court cited with approval article 21(2) of the African Children's Charter as follows: 148

Article 21 imposes on state parties, including Zimbabwe, an obligation which they voluntarily undertook to take all appropriate measures to eliminate harmful social and cultural practices affecting the welfare, dignity, normal growth and development of the child.

In addition, all three the selected countries have constitutionalised international standards for the protection of children's rights, which has had a considerable influence on law reform as well as on reasoning by the courts. ${ }^{149}$ For example, Sloth-Nielsen and Hove observe that 'section 78(1), dealing with marriage rights, and section 81 on children's rights in Zimbabwe are mirrored on direct provisions of international human rights standards'. ${ }^{150}$ Similar examples are to

144 National Registration Act, 2009.

145 Baseline for Selected Core Child Protection Indicators, presentation 19-20 November 2012.

146 See, eg, the Mudzuru case (n 99), and the Law Commission's respective reports on Malawi and South Africa.

147 Mudzuru (n 99) 27.

148 Mudzuru 37.

149 Secs 78(1), 28 and 23 of the Zimbabwean, South African and Malawian Constitutions, respectively.

150 Sloth-Nielsen \& Hove (n 109) 560-563. 
be found in sections 22, as amended, dealing with marriage, and section 23 on children's rights in the Malawian Constitution, ${ }^{\prime} 51$ as well as section 28 on children's rights in the South African Constitution.

More importantly, in addressing cultural practices that lead to child marriages, both Malawi and Zimbabwe have set the minimum age of marriage at 18 years for both boys and girls without exception. ${ }^{152}$ This is obviously a welcome departure from the position in South Africa, CRC and CRC/CEDAW which, in exceptional cases, allow the marriage of a minor who is above 16 years of age. ${ }^{153}$ Moreover, South Africa lays down different age groups for boys and girls in allowing child marriages.

Related to the age requirement, both parties to a marriage are required to give free and full consent, without providing room for parental consent. ${ }^{154}$ The importance of not making room for parental consent, in the fight against child marriages linked to cultural practices, cannot be overemphasised. It is generally observed that many child marriages linked to culture require the approval or consent of the parent or guardian. The position adopted by South Africa of allowing minors to get married with the consent of their parents in the Recognition of Customary Marriages Act and the Marriage Act, therefore, is regrettable. ${ }^{155}$ This has led to girls or women being married off to men they did not choose as long as the father's interests were met. ${ }^{156}$ However, the fact that child marriage predominantly occurs in rural areas where there are inadequate means of enforcing the law, let alone establishing the extent of the problem, ${ }^{157}$ ensures that the implementation of these laws remains a challenge. ${ }^{158}$

151 Sec 23 of the Malawian Constitution provides: '(1) All children, regardless of the circumstances of their birth, are entitled to equal treatment before the law. (2) All children shall have the right to a given name and family name and the right to a nationality. (3) Children have the right to know, and to be raised by their parents. (4) Children are entitled to be protected from economic exploitation or any treatment, work or punishment that is, or likely to - (a) be hazardous; (b) interfere with their education; or (c) be harmful to their health or to their physical, mental or spiritual or social development. (5) For purposes of this section, children shall be persons under sixteen years of age.'

152 See the Mudzuru judgment in Zimbabwe; and the Constitutional Amendment in Malawi.

153 CEDAW/CRC Recommendation/General Comment, 2014.

$154 \mathrm{Sec} 3(1)$ of the South African Recognition of Customary Marriages Act and sec 20(1) of the Zimbabwe Marriage Act.

155 See general discussions by TW Bennett Customary law in South Africa (2004) 203204.

156 Much was attributable to the custom of lobolo or bride price.

157 'Ending child marriage in Africa' https://www.hrw.org/news/2015/12/09/endingchild-marriage-africa (accessed 11 December 2017).

158 See discussions by L Mwambene \& $H$ Kruuse 'Form over function? The implementation of the Recognition of Customary Marriages Act, 1998' (2013) Acta Juridica 292. 
In addition, the recent reforms in Zimbabwe and Malawi also comply with international standards by adopting compulsory birth and marriage registration. ${ }^{159}$ As has been widely observed, the registration of both birth and marriage in the protection of children's rights has far-reaching consequences in the fight against child marriage. ${ }^{160}$ It can raise the alarm in cases where parties to the marriage are below the age of 18 years. The registration of births and marriages, however, remains a challenge. For example, the birth registration rate in Malawi is extremely low. In South Africa, the 2011 Baseline report estimates that fewer than 1 per cent of children between 0 and 2 years of age have birth certificates. In addition, in the context of South Africa, Women Gender Studies recorded that few marriages are registered. ${ }^{161}$

\subsection{Criminalisation of child marriages}

The approach adopted by Malawi, in addition to legislating the minimum age of marriage at 18 years, has criminalised child marriages. ${ }^{162} \mathrm{~A}$ similar approach is also seen in the Prohibition Bill in South Africa which, once it becomes law, seeks to criminalise child marriages. These trends, on the face of it, appear to give primacy to children's rights. ${ }^{163}$ They are also in line with the African Children's Charter and the African Women's Protocol, which oblige state parties to discourage child marriages. ${ }^{164}$ To this end, the criminalisation of child marriages is acceptable, not only as protection of children's rights, but also as sending out a clear message as to the true recognition of women's and children's rights, in particular their constitutional rights to human dignity and equality. ${ }^{165}$ However, several observations may be made that suggest some practical challenges in the implementation of this approach.

First, child marriage victims generally are incapable of pursuing any case due to a lack of resources or knowledge. Therefore, they would rely on their parents who often fail them. ${ }^{166}$ For example, it is reported that the ukuthwala victim in the South African case of Jezile $v R^{167}$ was returned by her own family members to the man

159 See, eg, the African Women's Protocol.

160 Mwambene \& Mawodza (n 55).

161 See also discussions by Mwambene \& Kruuse (n 161).

162 See, generally, the Prohibition Bill in the context of South Africa, and sec 83 of the Marriage Act (Malawi).

163 As provided for in international children's rights law, namely, CRC and the African Children's Charter.

164 Art 21(2) African Children's Charter.

165 See, eg, secs 10 and 9 of the South African Constitution, respectively.

$166 \mathrm{Eg}$, in the South African case of Jezile $v R$ (n 28), it is reported that the girl escaped from the village of the perpetrator and ran back to her family as she was not happy to be twalaed. Her family members took her back to the perpetrator.

167 In this case the accused, along with the complainant's uncle, arranged a customary marriage with the complainant, who was 14 years old, based on the ukuthwala custom in South Africa. The complainant attempted to escape twice, 
who had abducted her after she had escaped from his 'matrimonial home' ${ }^{168}$ Reflecting on the approach taken by the Prohibition Bill to punish parents, Mwambene and Mgidlana enquire as to how one can expect victims to send their own parents or family to prison. ${ }^{169}$ Therefore, it is suggested that criminalisation be coupled with measures that support child marriage victims to come forward, otherwise this might also be paper law.

In addition, some cultural and traditional practices may inhibit or act against the reforms that have taken place. For example, the Prohibition Bill seeks to outlaw any marriage that was concluded without the consent of the girl, a principle mirrored in international human rights standards. ${ }^{170}$ This principle, however, provides a stark reminder of some of the more specific and practical realities relating to the lives of children affected by child marriage. As previously observed, albeit in another context, Karimakwenda reminds us that 'consent is not easy to determine, particularly in the context of child marriage linked to ukuthwala' ${ }^{171}$ Addressing child marriage linked to harmful cultural practices, it has been suggested, 'requires a nuanced understanding of the social and central systems that govern customary marriages in a traditional community'. ${ }^{172}$

In addition, a close examination of the reforms reveals that the focus is geared towards punishing the perpetrator, and does not necessarily ensure the safety of the victim. ${ }^{173}$ This is problematic, as it would deter victims from coming forward to report such cases where their safety is not assured. In other words, such approaches would drive the cultural practices that lead to child marriage underground and frustrate all legal efforts to end child marriage in Southern Africa.

\section{Conclusion and recommendations}

Law reform to end child marriage, linked to practices embedded in culture, is considered a difficult task since it presents a potential conflict between children's rights and cultural rights. Zimbabwe,

and she suffered assaults and rape by the accused person. Her third attempt was successful and she informed the police. At the trial, the court held that the practice of ukuthwala did not entail the rape of a victim. As such, the accused's convictions on both the trafficking and rape counts were maintained by the High Court on appeal.

168 See Jezile $v R$ ( $\mathrm{n} 28)$

169 L Mwambene \& R Mgidlana 'Challenges of criminalising ukutwala in South Africa' (forthcoming).

170 See, eg, art 16 of CEDAW; art 6 of the African Women's Protocol; and art 8 of the SADC Gender Protocol.

171 See generally discussions by $\mathrm{N}$ Karimakwenda 'Today it would be called rape: A historical and contextual examination of forced marriage and violence in the Eastern Cape' (2013) Acta Juridica, 339. See also Mwambene \& Kruuse (n 8).

172 Mwambene \& Kruuse ( $\mathrm{n}$ 8).

173 See generally the Prohibition Bill 2015 and the Marriage, Divorce, and Family Relations Act, 2015. 
South Africa and Malawi, therefore, are to be lauded for their various positive law reforms. These laws present the potential to be instruments to fight child marriage.

However, an examination of the process leading to these reforms indicates that there are many aspects central to children's experiences in places where child marriage is most prevalent that have not been addressed. A crucial, and the most obvious, issue is poverty. ${ }^{174}$ It has been widely observed that poverty is behind most cultural practices such as lobolo (bride wealth), ukuthwala, kupimbira, and kuvarira. ${ }^{175}$ If efforts to end child marriage are to be meaningful to the children affected, it appears obvious that the process of law reform needs to be coupled with practical ways of addressing factors that perpetuate harmful cultural practices linked to child marriage.

Some practical ways, as proposed by the Girls Not Brides consortium, include mobilising communities to be agents of change and, more importantly, empowering girls. ${ }^{176}$ This bottoms-up approach, as championed by Channock, will ensure that 'change is grounded in peoples' reality and not just imposed on them' ${ }^{177}$ In addition, it is also obvious that, in the selected countries, the factors that lead to child marriage are not unique to the region. Therefore, much more can be learned from efforts of other countries, particularly in Northern Africa, where UNICEF has reported good progress in the fight against child marriage, a matter for discussion elsewhere. ${ }^{178}$

174 Research in Zimbabwe, South Africa and Malawi revealed that in communities where the level of poverty was high, the prevalence of child marriage was also high.

175 It has been widely reported that poverty is behind most cultural practices, such as lobolo (bride weath) (Zimbabwe, South Africa and Malawi); ukuthwala (Zimbabwe, South Africa and Malawi); kupimbira (Malawi); and kuvarira (Zimbabwe).

176 Girls Not Brides 'Theory for change' https://www.girlsnotbrides.org/childmarriage-theory-of-change/ (accessed 20 December 2017).

177 See, generally, M Channock 'African constitutionalism from the bottom-up' http:// www.customcontested.co.za/wp-content/uploads/2015/04/ChanockPublicLecture-2015.pdf (accessed 20 December 2017).

178 UNICEF https://data.unicef.org/wp-content/uploads/2015/11/UNICEF-Child-Marri age-Brochure-High-Single_246.pdf (accessed 11 December 2017). 